\title{
Glottic Cancer pT3 TNM Finding v7
}

National Cancer Institute

\section{Source}

National Cancer Institute. Glottic Cancer PT3 TNM Finding v7. NCI Thesaurus. Code C89067.

Glottic cancer with tumor limited to the larynx with vocal cord fixation and /or invasion of paraglottic space, and/or inner cortex of the thyroid cartilage. (from AJCC 7th Ed.) 